\title{
The influence of model grid resolution on estimation of national scale nitrogen deposition and exceedance of critical loads
}

\author{
A. J. Dore ${ }^{1}$, M. Kryza ${ }^{2}$, J. R. Hall ${ }^{3}$, S. Hallsworth ${ }^{1}$, V. J. D. Keller ${ }^{4}$, M. Vieno ${ }^{1}$, and M. A. Sutton ${ }^{1}$ \\ ${ }^{1}$ Centre for Ecology and Hydrology, Edinburgh, Scotland, UK \\ ${ }^{2}$ Department of Climatology and Atmospheric Protection, University of Wrocław, Poland \\ ${ }^{3}$ Centre for Ecology and Hydrology, Bangor, Wales, UK \\ ${ }^{4}$ Centre for Ecology and Hydrology, Wallingford, UK
}

Correspondence to: A. J. Dore (todo@ceh.ac.uk)

Received: 31 October 2011 - Published in Biogeosciences Discuss.: 15 December 2011

Revised: 3 April 2012 - Accepted: 4 April 2012 - Published: 3 May 2012

\begin{abstract}
The Fine Resolution Atmospheric Multi-pollutant Exchange model (FRAME) was applied to model the spatial distribution of reactive nitrogen deposition and air concentration over the United Kingdom at a $1 \mathrm{~km}$ spatial resolution. The modelled deposition and concentration data were gridded at resolutions of $1 \mathrm{~km}, 5 \mathrm{~km}$ and $50 \mathrm{~km}$ to test the sensitivity of calculations of the exceedance of critical loads for nitrogen deposition to the deposition data resolution. The modelled concentrations of $\mathrm{NO}_{2}$ were validated by comparison with measurements from the rural sites in the national monitoring network and were found to achieve better agreement with the high resolution $1 \mathrm{~km}$ data.

High resolution plots were found to represent a more physically realistic distribution of reactive nitrogen air concentrations and deposition resulting from use of $1 \mathrm{~km}$ resolution precipitation and emissions data as compared to $5 \mathrm{~km}$ resolution data. Summary statistics for national scale exceedance of the critical load for nitrogen deposition were not highly sensitive to the grid resolution of the deposition data but did show greater area exceedance with coarser grid resolution due to spatial averaging of high nitrogen deposition hot spots. Local scale deposition at individual Sites of Special Scientific Interest and high precipitation upland sites was sensitive to choice of grid resolution of deposition data. Use of high resolution data tended to generate lower deposition values in sink areas for nitrogen dry deposition (Sites of Scientific Interest) and higher values in high precipitation upland areas. In areas with generally low exceedance (Scotland) and for certain vegetation types (montane), the exceedance statistics were more sensitive to model data resolution.
\end{abstract}

\section{Introduction}

Emissions of reactive nitrogen to the atmosphere occur in the form of reduced nitrogen (ammonia gas) and oxidised nitrogen ( $\mathrm{NO}$ and $\mathrm{NO}_{2}$ ). The former is emitted predominantly from agricultural activities including emissions from farm animal wastes whilst the latter is generated from fuel combustion, notably power generation and road transport, as shown in the UK national atmospheric emissions inventory (http://naei.defra.gov.uk). $\mathrm{NO}_{2}$ and $\mathrm{NH}_{3}$ gas can be efficiently dry deposited to vegetation and, in the case of ammonia, deposition rates to acid grassland and forest are known to be particularly high due to low canopy resistance for these vegetation types. Atmospheric oxidation of $\mathrm{NO}_{\mathrm{x}}$ and chemical reaction can lead to the formation of nitric acid as well as ammonium and nitrate aerosols (Seinfield and Pandis, 1998). Particulates are associated with long range transport on scales of hundreds or even thousands of kilometres. However the efficiency of nitrate and ammonium aerosols to act as cloud condensation nuclei in the formation of rain clouds results in nitrogen being washed out of the atmosphere and wet deposited to the surface. Gases and particles may also be washed out of the boundary layer below cloud by falling rain drops (Seinfield and Pandis, 1998). Whilst the input of nitrogen to agricultural land is generally considered to be a desirable stimulus to productivity, the cycle of emissions and deposition of nitrogen to natural ecosystems has important consequences for changes to biodiversity and can lead to a decreasing incidence of nitrogen intolerant plant species which become replaced by nitrogen-loving plants. 
Heath-land communities are highly sensitive to $\mathrm{N}$ deposition. In areas with high $\mathrm{N}$ deposition, extensive loss of heather and conversion to grassland has been detected (Bobbink et al., 1998). Nitrogen deposition is also an important pathway leading to acidification of terrestrial and freshwater ecosystems (RoTAP, 2012). Together with habitat conversion and climate change, atmospheric deposition of reactive nitrogen has been recognised as one of the most significant threats to global biodiversity (Sala et al., 2000). Atmospheric nitrogen deposition also poses a serious threat to sensitive seminatural habitats in the UK (RoTAP, 2012).

Critical loads of nutrient nitrogen can be defined as "the highest deposition of nitrogen (as $\mathrm{NH}_{\mathrm{x}}$ and/or $\mathrm{NO}_{\mathrm{y}}$ ) below which harmful effects in ecosystem structure and function do not occur according to present knowledge" (UBA, 2004). Two approaches for assigning nutrient nitrogen critical loads are currently in use in the UK:

1. Empirical critical loads based on experimental data or field studies on observed changes in the structure or function of ecosystems in relation to nitrogen deposition (Achermann and Bobbink, 2003); these critical loads have been applied to unmanaged coniferous and broadleaved woodland categories, grassland (acid and calcareous), dwarf shrub heath, bog, montane, and dune grassland (Hall et al., 2003, 2011). The critical loads are expressed as ranges; the UK "mapping value" within each range is the value used for the calculation of critical load exceedances. The critical load mapping values applied in this study are given in Table 1 below.

2. Mass balance critical loads based on an equation which balances all significant long-term inputs and outputs of nitrogen to terrestrial systems; this equation is used to calculate critical loads for managed coniferous and broadleaved woodland habitats.

This approach, based on experimental data, has been adopted to set the critical loads referred to in this study. Nitrogen deposition for 2006-2008 exceeds the critical loads for nutrient $\mathrm{N}$ for $58 \%$ of the sensitive habitat areas of the UK; this is expected to decline to $48 \%$ by 2020 (RoTAP, 2012). The range of empirical critical loads for different ecosystem types is illustrated in Table 1.

Critical levels are the atmospheric concentrations of pollutants (e.g. ammonia) above which adverse effects on receptors (e.g. vegetation) may occur according to present knowledge (UBA, 2004).

The level of nitrogen deposition to natural ecosystems is assessed in many countries by national monitoring programmes to measure the concentrations of gases (ammonia and nitrogen di-oxide) and aerosols (ammonium and nitrate) in air as well as the chemistry of precipitation (i.e. UK Eutrophying and Acidifying Pollutants: http://pollutantdeposition. defra.gov.uk/ukeap). The long term maintenance of monitoring networks and chemical analysis of samples requires high levels of funding and inevitably imposes restrictions on the number of sites and therefore the spatial density at which measurements can be undertaken. Atmospheric transport models therefore represent an alternative and complimentary means of assessing nitrogen deposition. Use of past and future emissions estimates and meteorological data allows atmospheric transport models to calculate both historical and future projected nitrogen deposition (Matejko et al., 2009). For this reason, they are of particular use to policy makers to estimate the influence of measures to control emissions of reactive nitrogen to the atmosphere. Despite the fact that models require simple parameterisation of highly complex meteorological, physical and chemical processes in the atmosphere, they are able to provide reasonable estimates of nitrogen deposition to natural ecosystems (Carslaw, 2011). Models have the added advantage that calculations are made at a large number of model grid cells, invariably with much higher spatial density than that which can be achieved by surface monitoring of concentrations in air and precipitation. Remote sensing from satellites has however been demonstrated to be an effective technique to measure gaseous nitrogen compounds in air with global coverage (Clarisse et al., 2009).

Significant differences in estimation of the exceedance of critical loads may be obtained with different modelling techniques. Choice of chemical parameterisation, calculation of deposition velocities and estimation of precipitation are all factors which can lead to a divergence amongst models in their estimation of nitrogen deposition.

The seeder-feeder effect is explicitly represented in FRAME (Fournier et al., 2005) with an enhanced washout coefficient applied to orographic rain. This simulates the efficient removal of particulate nitrogen incorporated in cloud droplets and washed out from precipitation from above. Eulerian models, i.e. EMEP (Fagerli et al., 2011; Vieno et al., 2010a) and CMAQ (Chemel et al., 2010) have more complex microphysical schemes for formation of rain and cloud but do not explicitly include a parameterisation of the seederfeeder effect. The representation of land cover and deposition to different vegetation types may vary between models and their applications. Whilst some applications use a dominant land category to derive deposition in each model grid square, others calculate deposition explicitly to different land categories. For ammonia gas in particular, the dry deposition velocity may be approximately an order of magnitude higher for forest and acid grassland than for improved grassland. Five different land classes are represented in FRAME (forest, semi-natural grassland, improved grassland, arable and urban). In the EMEP model 16 land classes are used, including sub-divisions of the arable and forest classes for detailed ecosystem effects studies.

The spatial resolution at which calculations can be made with an atmospheric transport model depends on a number of factors. These include the size of the model domain, available computational power and the degree of complexity of the 
Table 1. Ranges of empirical critical loads of nutrient nitrogen and UK mapping values.

\begin{tabular}{|c|c|c|c|}
\hline Ecosystem type & EUNIS code ${ }^{a}$ & $\begin{array}{l}\text { CLnutN range } \\
2003^{\mathrm{b}} \\
\left(\mathrm{kg} \mathrm{Nha}^{-1} \mathrm{yr}^{-1}\right)\end{array}$ & $\begin{array}{l}\text { UK CLnutN mapping } \\
\text { value } 2003^{\mathrm{f}} \\
\left(\mathrm{kg} \mathrm{Nha}^{-1} \mathrm{yr}^{-1}\right)\end{array}$ \\
\hline \multicolumn{4}{|l|}{ Coastal habitats } \\
\hline Shifting coastal dunes & B 1.3 & $10-20^{\mathrm{e}}$ & 15 \\
\hline Stable dune grasslands & B1.4 & $10-20^{\mathrm{d}}$ & 15 \\
\hline \multicolumn{4}{|l|}{ Mire, bog and fen habitats } \\
\hline Raised and blanket bogs & D1 & $5-10^{\mathrm{c}}$ & 10 \\
\hline \multicolumn{4}{|l|}{ Grasslands and tall forb habitats } \\
\hline Semi-dry calcareous grassland & E1.26 & $15-25^{\mathrm{c}}$ & 20 \\
\hline Dry acid grassland & E1.7 & $10-20^{\mathrm{d}}$ & 15 \\
\hline Moist/wet oligotrophic grassland & E3.52 & $10-20^{\mathrm{d}}$ & 15 \\
\hline Moss and lichen dominated montane & E4.2 & $5-10^{\mathrm{d}}$ & 7 \\
\hline \multicolumn{4}{|l|}{ Heathland, scrub and tundra } \\
\hline Upland Calluna-dominated wet heath & $\mathrm{F} 4.11(\mathrm{U})$ & $10-20^{\mathrm{e}}$ & 15 \\
\hline Lowland Erica tetralix-dominated wet heath & F4.11(L) & $10-25^{\mathrm{e}}$ & 15 \\
\hline Dry heath & $\mathrm{F} 4.2$ & $10-20^{\mathrm{c}}$ & 12 \\
\hline \multicolumn{4}{|l|}{ Forest habitats } \\
\hline Unmanaged woodland (to protect ground flora) & G & $10-15^{\mathrm{d}}$ & 12 \\
\hline Unmanaged woodland (to protect epiphytic lichens and algae) & G & $10-15^{\mathrm{e}}$ & 10 \\
\hline
\end{tabular}

${ }^{a}$ Habitat class according to the European Nature Information System (EUNIS) (Davies et al., 2004). ${ }^{\mathrm{b}}$ Ranges and reliability scores of critical loads (Achermann and Bobbink, 2003); these have been updated since the analysis for this paper was undertaken, see Bobbink and Hettelingh (2011). Reliability scores:

${ }^{c}$ Reliable: when a number of published papers of various studies showed comparable results. ${ }^{\mathrm{d}}$ Quite reliable: when the results of some studies were comparable.

e Expert judgement: when no empirical data were available for this type of ecosystem. For this, the nitrogen critical load was based upon expert judgement and knowledge of ecosystems which were likely to be comparable with this ecosystem. ${ }^{\mathrm{f}}$ UK mapping values (Hall et al., 2003); these have been updated since the analysis for this paper was undertaken, see Hall et al. (2011).

model. Inevitably, highly complex model simulations over large spatial domains will have limits imposed on grid resolution by the available computer facilities. Furthermore, fine spatial scale assessment of nitrogen deposition requires high resolution input data for meteorology as well as maps of land use and reactive nitrogen emissions.

Most atmospheric transport models use grid nesting to pass information from a large scale (i.e. continental) simulation with a coarse grid spacing to a regional scale (typically national) with finer grid spacing (i.e. Chemel et al., 2010; Vieno et al., 2010a). The OPS model represents a combination of a Gaussian plume model for local-scale application and a trajectory model for long-range transport operating on grid scales of $5 \mathrm{~km}$ and $500 \mathrm{~m}$ (Van Pul et al., 2004). The model was used to simulate concentrations, deposition and budgets of $\mathrm{NH}_{3}$ gas and $\mathrm{NH}_{4}^{+}$aerosol for the Netherlands. The Danish Ammonia Modelling system (DAMOS) uses a combination of a long range transport model and a Gaussian local scale transport-deposition model for dry deposition. The long range transport model operates on a variety of scales with two-way nesting, from $150 \mathrm{~km}$ for the Northern Hemisphere, $50 \mathrm{~km}$ for Europe and $16.7 \mathrm{~km}$ for Denmark. Ammonia emissions are computed with high spatial resolution at a single farm and field level (Gyldenkaerne et al., 2005) and include detailed temporal profiles for both the seasonal and diurnal variation in ammonia emissions (Skjøth et al., 2011). Application of the model showed that the deposition of nitrogen exceeded the critical load at many sites in western Denmark due to a combination of long range transport of nitrogen aerosol and the deposition of ammonia gas from local livestock sources (Hertel et al., 2012). Validation of the model with measurements (Geels et al., 2012) illustrated the importance of including both fine scale local scale modelling and regional scale simulation. Appel et al. (2011) compared the results of simulations with the CMAQ model over the USA at resolutions of $12 \mathrm{~km}$ and $36 \mathrm{~km}$ with measurements from the National Atmospheric Deposition Programme. The under-estimate in concentration of ammonium in precipitation by the model showed a small but significant improvement with the finer resolution simulation. The normalised mean bias was between $-10 \%$ and $-16 \%$ for the $12-\mathrm{km}$ simulation and $-12 \%$ to $-18 \%$ for the $36 \mathrm{~km}$ simulation. A similar improvement was found for nitrate concentration in precipitation for the higher resolution simulation. Vogt et al. (2012) calculated ammonia concentrations and deposition at a $25 \mathrm{~m}$ resolution in an agricultural landscape. A landscape-resolved emissions map was input to a Lagrangian local dispersion model and the modelled concentrations were compared with measurements from a dense network of passive diffusion and denuder samplers. Fine resolution model simulation was demonstrated to be necessary to reproduce the measured ammonia concentrations. A detailed discussion 
of modelling nitrogen deposition at a local scale is presented in Hertel et al. (2006). The high resolution in the inventories was shown to be important for the model performance.

The choice of model grid resolution can influence results in different ways:

Spatial Averaging: Spatial averaging of both input data and output modelled air concentrations and surface deposition can have important implications. In the real atmosphere, gas concentrations of reactive nitrogen in air may vary significantly on the scale of a few tens of metres in the vicinity of a strong emissions source such as a road or poultry shed. In reality however, national and continental scale modelling assessments are typically practical at grid resolutions in the range of $1 \mathrm{~km}$ for simple models (Hallsworth et al., 2010), $5 \mathrm{~km}$ for regional Eulerian models (i.e. Vieno et al., 2010a) to $50 \mathrm{~km}$ for continental simulations (Fagerli et al., 2011). Finer resolution data, averaged over smaller areas can more effectively capture hot spots of high concentrations and deposition, leading to different results for assessment of the exceedance of critical loads and levels (Hallsworth et al., 2010).

Process Rate: The processes parameterised in the model simulation may behave differently depending on grid resolution. One example of this is the representation of orographic precipitation in meteorological models (Richard et al., 2007). It has been observed that with a larger grid resolution of $50 \mathrm{~km}$, the influence of hills in generating orographically enhanced precipitation in the UK was not effectively captured. A $5 \mathrm{~km}$ simulation generated significantly higher precipitation in hill areas (RoTAP, 2012). A second example is the rate of chemical transformation in the atmosphere. Larger model grid sizes result in more instantaneous mixing of emitted acid gases $\left(\mathrm{NO}_{\mathrm{x}}\right.$ and $\left.\mathrm{SO}_{2}\right)$ with ammonia $\left(\mathrm{NH}_{3}\right)$. This may lead to enhanced chemical reaction rates and more rapid formation of ammonium nitrate and ammonium sulphate aerosol particles.

The Fine Resolution Atmospheric Multi-pollutant Exchange model FRAME (Singles et al., 1998; Fournier et al., 2004; Dore et al., 2007; Vieno et al., 2010b) is a Lagrangian Atmospheric Transport Model. Its relatively simple dynamic framework and chemical schemes result in fast run times. The model is therefore well suited to high resolution national scale simulations, which are currently too computationally demanding for more complex Eulerian models. The aim of this work is to investigate the influence of spatial averaging of modelled air concentrations and deposition (effect 1 above) on the exceedance of critical loads for nitrogen deposition.

The results of a $1 \mathrm{~km}$ model simulation have been mapped at resolutions of $1 \mathrm{~km}, 5 \mathrm{~km}$ and $50 \mathrm{~km}$. The $1 \mathrm{~km}$ resolution data represents a recent development in the capability of the model (Hallsworth et al., 2010) whereas previous studies were undertaken using $5 \mathrm{~km}$ resolution data. $50 \mathrm{~km}$ resolution data is of interest as this is the resolution of the EMEP model (Fagerli et al., 2011) used at a European scale to provide support for the Convention on Long Range Transport of Air Pollutants. This ensures that total national scale deposition is conserved. The three data sets have been compared spatially and assessed by validation with measurements of $\mathrm{NO}_{2}$ gas concentrations. The different resolution data have been used to assess the sensitivity of model grid resolution on the exceedance of critical loads for nitrogen deposition in the UK. The influence of model grid resolution on $\mathrm{NO}_{2}$ concentrations near a Site of Special Scientific Interest (SSSI) and on wet deposition of nitrate in a high precipitation upland region is considered.

\section{Model description}

The FRAME model was initially developed to calculate spatially distributed deposition of reduced nitrogen for the United Kingdom (Singles et al., 1998). It was subsequently improved to include a detailed representation of oxidised nitrogen and sulphur deposition (Fournier et al., 2004; Dore et al., 2007; Vieno et al., 2010b) to be used for assessment of the exceedance of critical loads for nitrogen deposition and acid deposition (Matejko et al., 2009). Other regional scale applications of the model include estimation of ammonia concentrations and deposition of reduced nitrogen in Poland (Kryza et al., 2011) and application to the North China Plains (Zhang et al., 2011), an area demonstrated by remote sensing to be a global hot spot for ammonia concentrations (Clarisse et al., 2009). The relative simplicity of the model corresponds to a fast simulation time (of approximately $12 \mathrm{~h}$ for a $1 \mathrm{~km}$ resolution using 24 processors on a High Performance Computational Linux cluster).

A summary of the main features of the FRAME model is given below:

$-5 \times 5 \mathrm{~km}$ or $1 \times 1 \mathrm{~km}$ resolution over the British Isles (incorporating the Republic of Ireland).

- Input gas and aerosol concentrations at the edge of the UK model domain are calculated with FRAME using a European-scale simulation run on the EMEP $50 \mathrm{~km}$ scale grid and emissions provided from the EMEP data base (Cooperative Programme for Monitoring and Evaluation of the Long-range Transmission of Air Pollutants in Europe http://www.emep.int/UniDoc/index.html).

- Air column divided into 33 layers moving along straight-line trajectories in a Lagrangian framework with a $1^{\circ}$ angular resolution. The air column advection speed and frequency for a given wind direction is statistically derived from radio-sonde measurements (Dore et al., 2006a). Variable layer thickness from $1 \mathrm{~m}$ at the surface to $100 \mathrm{~m}$ at the top of the mixing layer. 


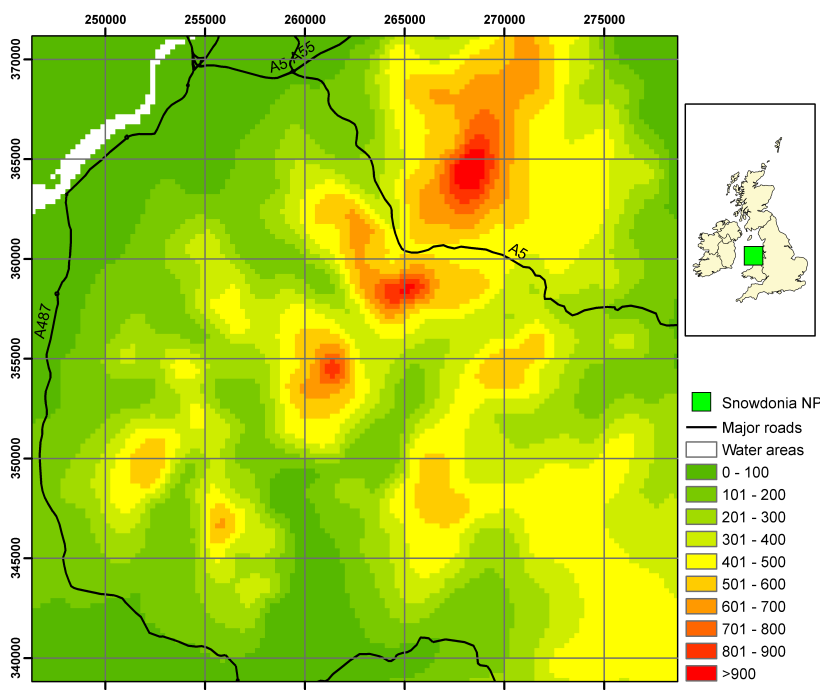

Fig. 1a. Terrain elevation in the region of Snowdonia, North Wales (ma.s.1.).

- Emissions are gridded separately by SNAP (Selected Nomenclature for Air Pollution) sector for $\mathrm{SO}_{2}$ and $\mathrm{NO}_{\mathrm{x}}$ using emissions data from the National Atmospheric Emissions Inventory (http://naei.defra.gov.uk/) for the year 2007, gridded at a $1 \mathrm{~km}$ resolution. $\mathrm{NH}_{3}$ emissions were input by agricultural sector and injected into vertical model layers which depend on the sector.

- Vertical diffusion in the air column is calculated using K-theory eddy diffusivity and solved with the Finite Volume Method.

- Wet deposition is calculated using a scavenging coefficient and a "constant drizzle" approximation driven by an annual rainfall map. A precipitation model is used to calculate wind-direction-dependent orographic enhancement of wet deposition (Fournier et al., 2005).

- Five land classes: forest, moorland, improved grassland, arable, urban and water are considered. The parameterisation employed to calculate dry deposition of $\mathrm{SO}_{2}$, $\mathrm{NO}_{\mathrm{x}}$ and $\mathrm{NH}_{3}$ includes vegetation specific canopy resistance and surface roughness.

- The model chemistry includes gas phase and aqueous phase reactions of oxidised sulphur and oxidised nitrogen and conversion of $\mathrm{NH}_{3}$ to ammonium sulphate and ammonium nitrate aerosol.

Complex Eulerian models employing dynamical meteorological drivers such as CMAQ (Chemel et al., 2011) and EMEP4UK (RoTAP, 2012) have also been employed to calculate national scale nitrogen deposition in the UK. Such models can calculate temporally resolved deposition and concentration and their dependence on variable dynamic meteorology. Validations of different models against annually

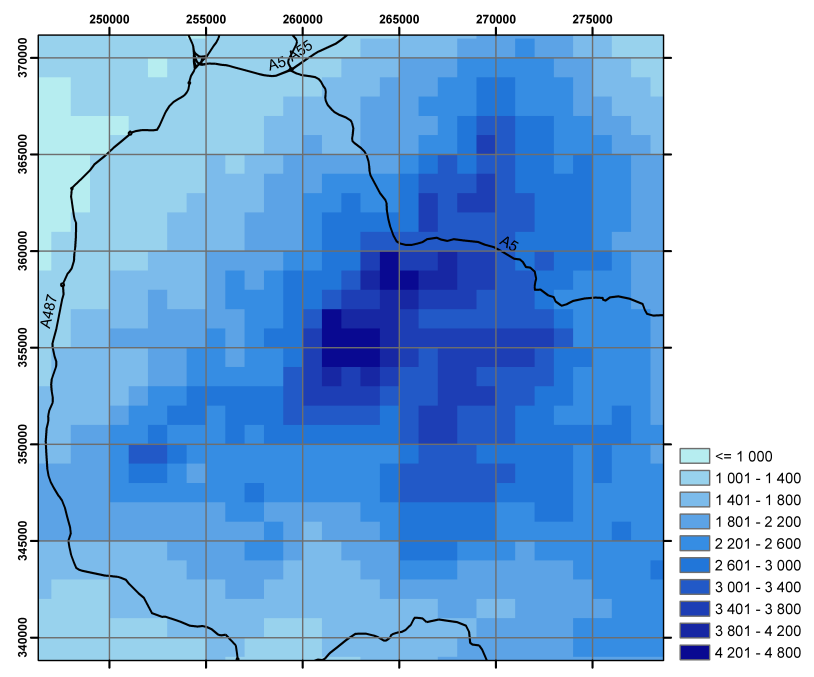

Fig. 1b. Annual precipitation $(\mathrm{mm})$ gridded at a $1 \mathrm{~km}$ resolution for Snowdonia.

averaged measurements have been undertaken by Chemel et al. (2011) and Carslaw (2011). Despite its relatively simple approach, FRAME still offers certain advantages in calculating surface gas concentrations due to its fine vertical grid spacing ( $1 \mathrm{~m}$ at the surface) and detailed treatment of plume rise for point sources as well as in wet deposition due to use of a precipitation map generated from measurements. This resulted in good correlation with measurements of gas concentrations $\left(\mathrm{NH}_{3}, \mathrm{NO}_{2}, \mathrm{SO}_{2}\right)$ and an overall reasonable performance when compared to more complex models.

Previous national scale applications of the FRAME model (Dore et al., 2007; Vieno et al., 2010b; Matejko et al., 2009; Kryza et al., 2011) were undertaken with a $5 \mathrm{~km}$ grid resolution. The development of the FRAME model at a $1 \mathrm{~km}$ resolution over the UK and application to assess exceedance of the critical level for ammonia concentration in air over Natura 2000 sites (Special Protection Areas and Special Areas of Conservation) is described in Hallsworth et al. (2010). The study showed that a $1 \mathrm{~km}$ model simulation generated significantly lower values for the percentage of land surface area in nature sites with concentrations of ammonia in air exceeding the critical levels of 1 and $3 \mu \mathrm{g} \mathrm{m}^{-3}$ when compared to $5 \mathrm{~km}$ resolution model data. This was attributed to the better spatial separation of agricultural source emissions areas for ammonia from sink nature reserve areas with the fine resolution study.

\section{Input data}

\subsection{Emissions}

The UK National Atmospheric Emissions Inventory is updated on an annual basis and provides spatially disaggregated maps of a range of pollutant emissions at a $1 \mathrm{~km}$ resolution. 


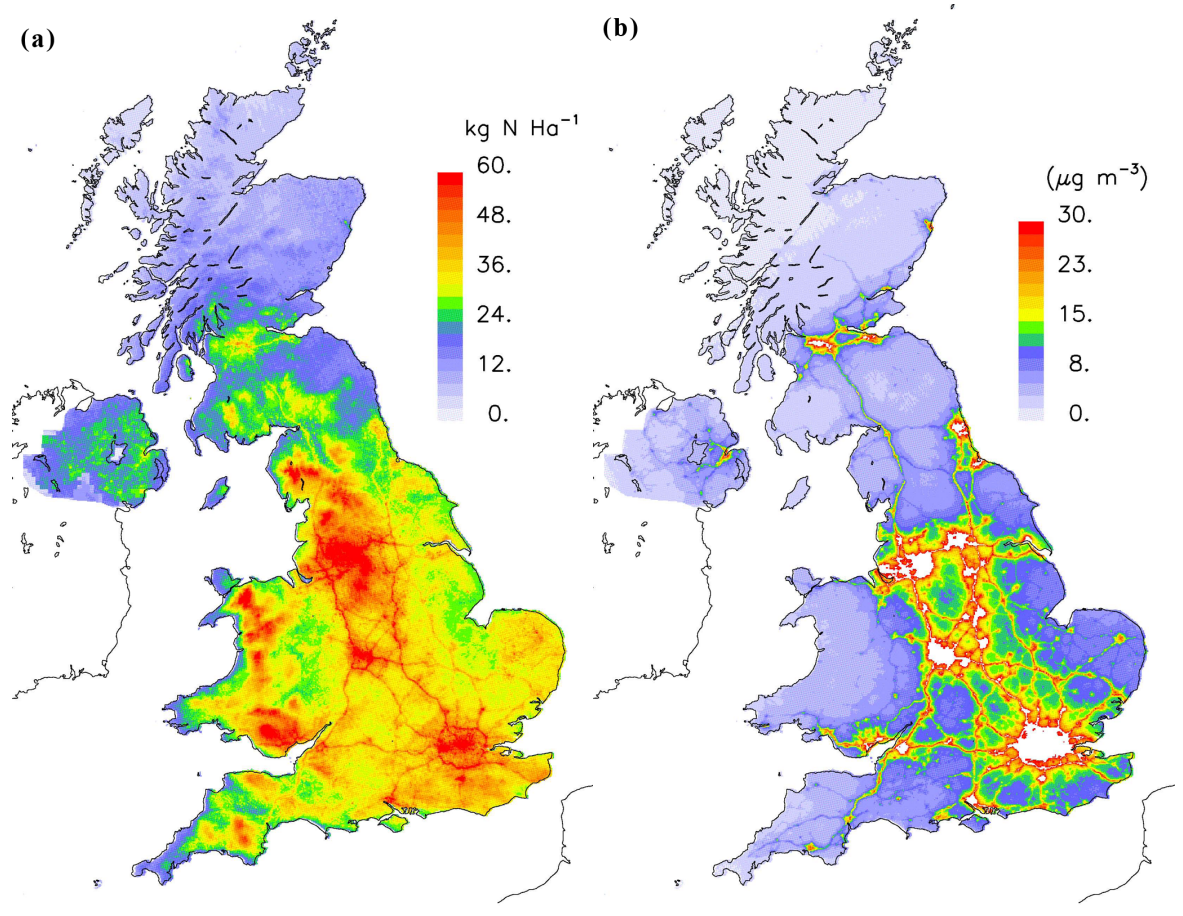

Fig. 2. (a) Total nitrogen deposition in the UK (left). (b) $\mathrm{NO}_{\mathrm{x}}$ concentration in air (right) for the year 2007 calculated with the FRAME model at a $1 \mathrm{~km}$ resolution. $\mathrm{NO}_{\mathrm{x}}$ concentrations above the $30 \mu \mathrm{g} \mathrm{m}^{-3}$ critical level are shown in white.

Whilst atmospheric transport models have the potential for improved performance by use of high spatial resolution studies, it should be noted that the benefits depend strongly on the accuracy of high resolution input data, in particular emissions.

In the case of $\mathrm{NO}_{\mathrm{x}}$ emissions, the location of emissions (from vehicles travelling along roads and from major point source combustion sources) is well known. However due to the large number of different vehicles using the roads, there is uncertainty in emissions factors for $\mathrm{NO}_{\mathrm{x}}$ from vehicles as well as how this may change in time for older vehicles. Road traffic is monitored at many locations throughout the country. However in rural areas, there may be greater uncertainty in mapping emissions in the vicinity of minor roads.

Emissions of ammonia are predominantly from agriculture and in particular due to direct emissions from livestock manure. Total annual emissions are estimated based on census data of farm animals and estimates of emissions factors per animal. The spatial distribution of agricultural ammonia emissions uses census data at a parish level and distributes emissions within each parish according to land use category and its suitability for agriculture. Emissions of ammonia from a wide range of non-agricultural sources are also included (Sutton et al., 2000). In general the spatial distribution of ammonia emissions from agriculture are associated with higher uncertainty than $\mathrm{NO}_{\mathrm{x}}$ emissions. The concentration and deposition of ammonia has been demonstrated to vary significantly over short distances (Fowler et al., 1998).

\subsection{Precipitation}

An annual precipitation map of the UK at a $1 \mathrm{~km}$ resolution was generated using data from 6000 daily measurement sites and 13100 monthly measurement sites in the UK Met Office national precipitation monitoring network (Keller et al., 2006). The triangular planes methodology was used to generate daily $1 \mathrm{~km}^{2}$ rainfall grids using a weighted average based upon the inverse distance of the three nearest rain gauges. The gridded rainfall data were then normalised and the daily rainfall totals were summed to give annual precipitation. The technique was successfully validated by comparison of the calculated rainfall data with site measurements (not included in the calculation) both for specific precipitation events and for monthly totals. As the measurement of rainfall with standard rain gauges is a simple and accurate process, this technique can produce a relatively precise precipitation map. Standard measurement error due to undercapture is typically about $5 \%$ (Keller et al., 2006). Measurements in upland regions, with more highly spatially variable precipitation, are less concentrated. This will therefore result in greater uncertainty in precipitation and therefore nitrogen deposition in the high rainfall regions, which also contain sensitive ecosystems. More complex Eulerian models (Vieno et al., 2010a; Chemel et al., 2010) dynamically generate precipitation with a meteorological model. However, modelled estimates of precipitation are known to be subject to considerable uncertainty. 


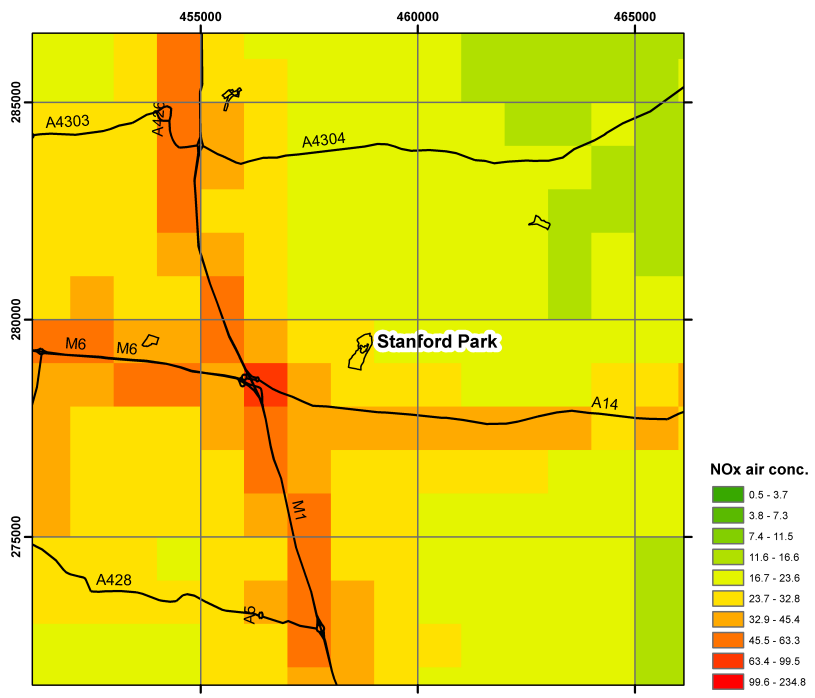

Fig. 3a. $\mathrm{NO}_{\mathrm{x}}$ air concentrations at Stanford Park SSSI $\left(\mu \mathrm{g} \mathrm{m}^{-3}\right)$ with $1 \mathrm{~km}$ grid resolution.

In this study we focus on nitrogen deposition in the UK as a whole as well as a region of highly variable precipitation in Snowdonia in North Wales. Figure 1a and b illustrate the topography of the region and gridded precipitation data at a resolution of $1 \mathrm{~km}$.

The Snowdonia region is located near the west coast of North Wales and contains steep peaks of altitude exceeding $1000 \mathrm{~m}$ separated by broad valleys. The orography in the region has a strong influence on annual precipitation which varies from $1200 \mathrm{~m}$ near the west coast to approximately $4000 \mathrm{~m}$ in the region of Mt. Snowdon and varies significantly at a $1 \mathrm{~km}$ resolution scale. Precipitation in this region is strongly influenced by the seeder-feeder effect (Fowler et al., 1988). The ascent and cooling of moist boundary layer air in prevailing winds frequently leads to the formation of low-level hill clouds. Whilst these clouds are generally too short lived to form into rain, their cloud droplets can be efficiently washed out by rain drops falling from higher level frontal rain clouds. A study of precipitation and wet deposition in this region using a simple model of the seeder-feeder effect is described in Dore et al. (2006b). The high precipitation resulted in high levels of deposition of sulphur and nitrogen and exceedance of critical loads for acid deposition and nitrogen deposition.

\section{Results and discussion}

\subsection{Nitrogen concentration and deposition}

The concentrations of reactive nitrogen compounds in air as well as nitrogen deposition to the surface were calculated with FRAME at a $1 \mathrm{~km}$ resolution for the UK for the year 2007. The model output was aggregated by calculating the average of the $1 \mathrm{~km}$ gridded data at spatial resolutions of

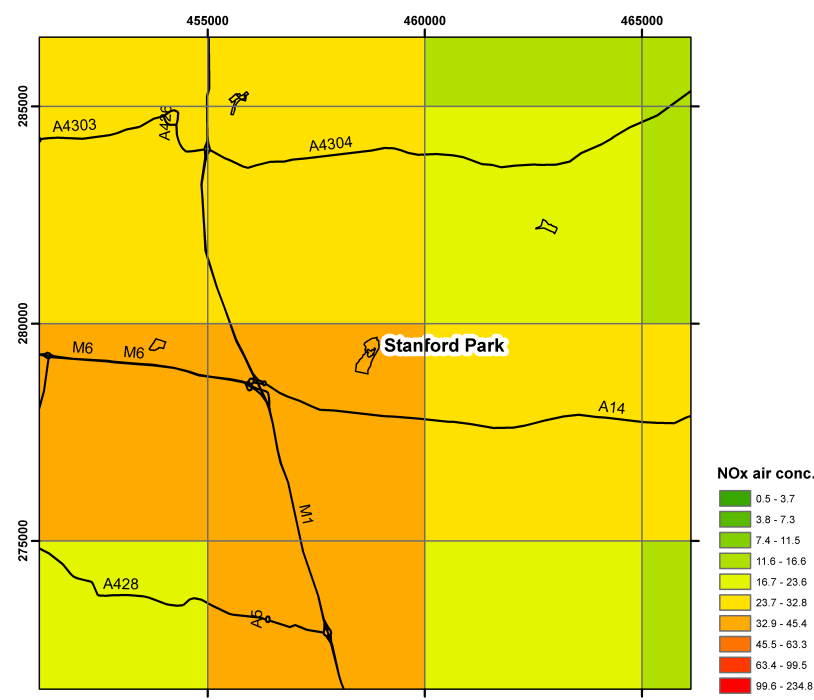

Fig. 3b. $\mathrm{NO}_{\mathrm{x}}$ air concentrations at Stanford Park SSSI $\left(\mu \mathrm{g} \mathrm{m}^{-3}\right)$ with $5 \mathrm{~km}$ grid resolution.

$5 \mathrm{~km}$ and $50 \mathrm{~km}$. This data was then used to investigate the influence of model grid resolution on the exceedance of critical loads for nitrogen deposition.

Figure 2a illustrates the deposition of nitrogen for the UK calculated by FRAME at a $1 \mathrm{~km}$ resolution. A general trend in the deposition of nitrogen deposition, decreasing from south to north is apparent. This is caused by more intense industrial and agricultural activity in the south of the country as well as greater proximity to major sources of emissions of reactive nitrogen from other European countries and from international shipping in the English Channel. Local areas of high nitrogen deposition are also evident in the vicinity of intensive agricultural areas (due to cattle farming in western England and pig and poultry farming particularly in East Anglia) and in upland regions with high precipitation: North Wales; the Pennines (northern England); the Lake District (north-west England).

High nitrogen deposition can be seen close to major cities (i.e. London, Birmingham, Manchester) and along major highways, due to high $\mathrm{NO}_{\mathrm{x}}$ concentrations from road transport. The critical level for $\mathrm{NO}_{\mathrm{x}}$ concentrations as applied to natural ecosystems has been set as $30 \mu \mathrm{g} \mathrm{m}^{-3}$ (UBA, 2004). As illustrated in Fig. 2b this concentration is exceeded in areas of high road transport intensity, calculated with the model to be $5.2 \%$ of the total area of the UK. However, it is important to note that these emission source areas have a high density of urban land area and a relatively low coincidence with natural ecosystems. Comparison with the $1 \mathrm{~km}$ resolution land cover map used in FRAME showed that exceedance of the critical load for $\mathrm{NO}_{\mathrm{x}}$ concentrations occurred over $33.4 \%$ of urban land area. $4.2 \%$ of forested land and $2.1 \%$ of land with semi-natural grass land was calculated to have annual $\mathrm{NO}_{\mathrm{x}}$ concentrations in exceedance of the critical level. 


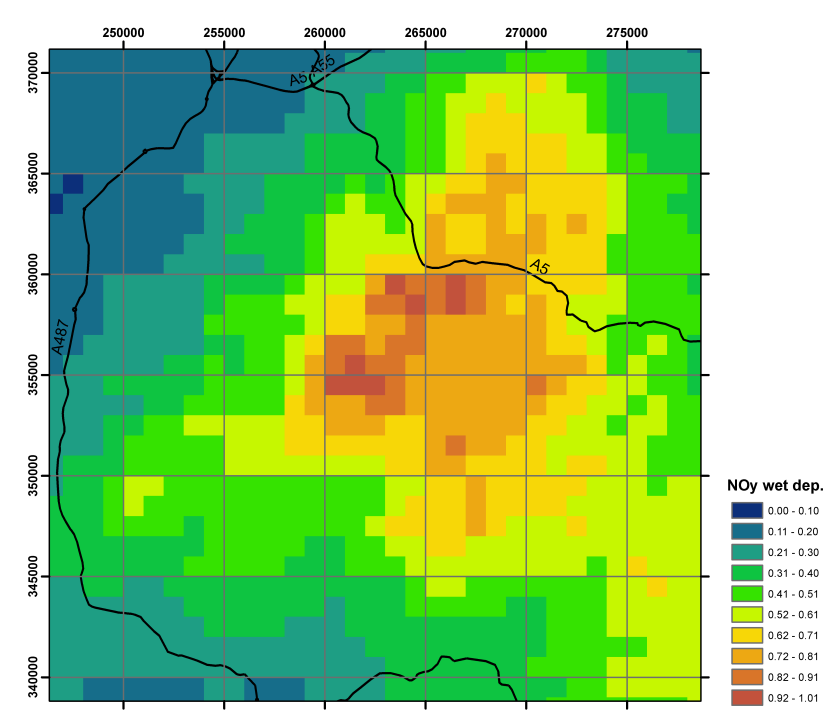

Fig. 4a. $\mathrm{NO}_{\mathrm{y}}$ wet deposition in Snowdonia $\left(\mathrm{keq} \mathrm{ha}^{-1}\right)$ with $1 \mathrm{~km}$ grid resolution.

Figure 3 shows comparisons of $\mathrm{NO}_{\mathrm{x}}$ concentrations generated with FRAME and gridded at both $1 \mathrm{~km}$ and $5 \mathrm{~km}$ resolutions at Stanford Park, a 20 ha site of midland clay pastures, designated Site of Special Scientific Interest, which is located approximately one $\mathrm{km}$ away from a major road. With the $1 \mathrm{~km}$ data, the $\mathrm{NO}_{\mathrm{x}}$ concentrations are more closely correlated with the locations of the roads, in a more physically realistic manner. This resulted in lower $\mathrm{NO}_{\mathrm{x}}$ concentrations being assigned to the grid square containing the SSSI. The $1 \mathrm{~km}$ gridded data therefore represents an improved spatial distribution of air pollutant concentrations. However, even with $1 \mathrm{~km}$ data, strong spatial gradients in air concentrations may occur as a result of the physical limitations of the specified model grid. For focused local scale studies, dedicated local scale dispersion models are preferable (i.e. Chaney et al., 2011). Examples of such models, which are commonly applied to simulate dispersion of line and point source emissions in urban and suburban areas at grid resolutions of tens to hundred of metres, include ADMS and AEROMOD (i.e. Carruthers et al., 2011). Despite these considerations, the $1 \mathrm{~km}$ resolution simulation of nitrogen deposition data generated with FRAME represents an improved reference national data set for sites where data from local scale dispersion studies is not available.

Figure 4 illustrates $\mathrm{NO}_{\mathrm{y}}$ wet deposition in Snowdonia gridded at resolutions of both $1 \mathrm{~km}$ and $5 \mathrm{~km}$. Precipitation in hill areas is known to vary significantly over relatively small distances. This can lead to hot spots in wet deposition which are captured by $1 \mathrm{~km}$ resolution data but less evident with $5 \mathrm{~km}$ resolution data due to spatial smoothing over wider areas incorporating both hill peaks and lowlands.

The data presented here compares concentrations and deposition from a $1 \mathrm{~km}$ resolution simulation with those

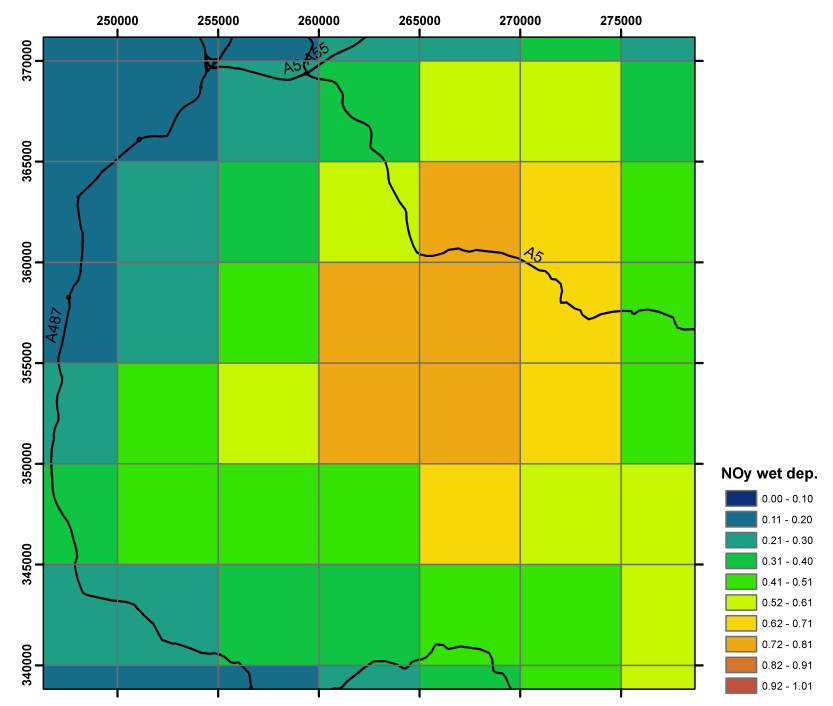

Fig. 4b. $\mathrm{NO}_{\mathrm{y}}$ wet deposition in Snowdonia $\left(\mathrm{keq} \mathrm{ha}^{-1}\right)$ with $5 \mathrm{~km}$ grid resolution.

re-gridded at resolutions of 5 and $50 \mathrm{~km}$. This ensures conservation of mass when comparing the exceedance of critical loads. However it is also of interest to compare the results of the $1 \mathrm{~km}$ resolution simulation with those from a simulation with a model grid resolution of $5 \mathrm{~km}$ (effect 2 , as discussed in the introduction). The comparison showed that the chemical transformation rate from gas to aerosol was somewhat more rapid with the $5 \mathrm{~km}$ resolution simulation. This can be attributed to the increased instantaneous mixing of ammonia with acid gases in the coarser resolution simulation. This resulted in lower dry deposition of nitrogen (mostly from $\mathrm{HNO}_{3}, \mathrm{NO}_{2}$ and $\mathrm{NH}_{3}$ gas) and higher wet deposition (predominantly due to washout of ammonium and nitrate aerosol). National deposition of reduced and oxidised nitrogen was higher by $2 \%$ and $7 \%$ respectively with the $5 \mathrm{~km}$ resolution simulation.

\subsection{Comparison with measurements of $\mathrm{NO}_{2}$}

Model performance may be assessed by validation with measurements from national monitoring networks. A comparison of model correlation with measurements of ammonia concentrations using both $1 \mathrm{~km}$ and $5 \mathrm{~km}$ resolution data has been undertaken by Hallsworth et al. (2010). This demonstrated an improvement in correlation with measurements and a reduction in model over-estimate of ammonia concentration at semi-natural sites with use of the $1 \mathrm{~km}$ resolution model data. An overview of model performance for gas and aerosol concentrations of sulphur and nitrogen compounds as well as precipitation concentrations is given in Dore et al. (2007) and Carslaw (2011). Correlation with measurements of wet deposition of nitrogen was found not to be significantly improved with use of $1 \mathrm{~km}$ resolution data. This was attributed to the fact that precipitation is highly spatially 

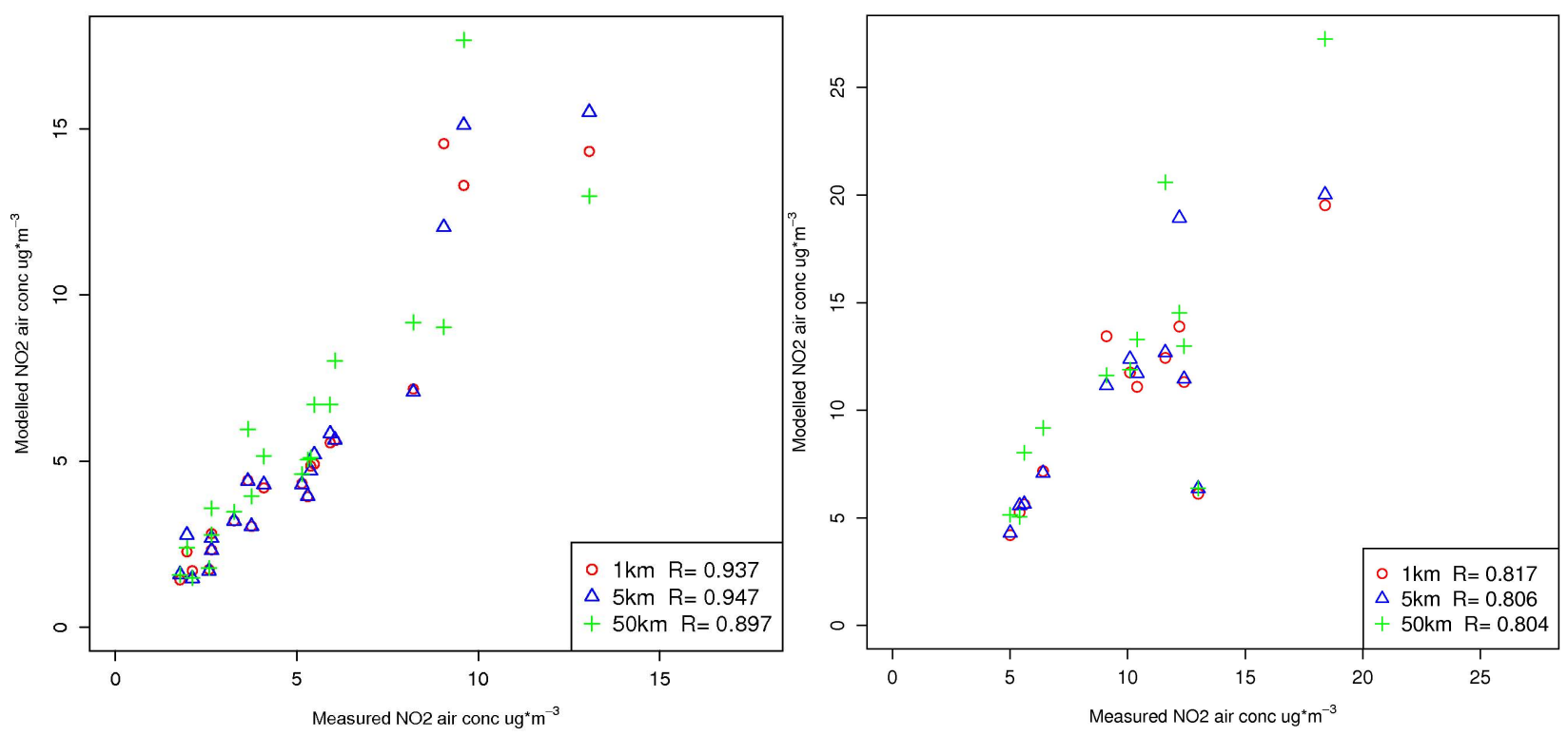

Fig. 5. Correlation with measurements of $\mathrm{NO}_{2}\left(\mu \mathrm{g} \mathrm{m}{ }^{-3}\right)$ from the rural monitoring network (left) and rural sites in the Automatic Urban and Rural monitoring Network (right) for $1 \mathrm{~km}, 5 \mathrm{~km}$ and $50 \mathrm{~km}$ model resolution data.
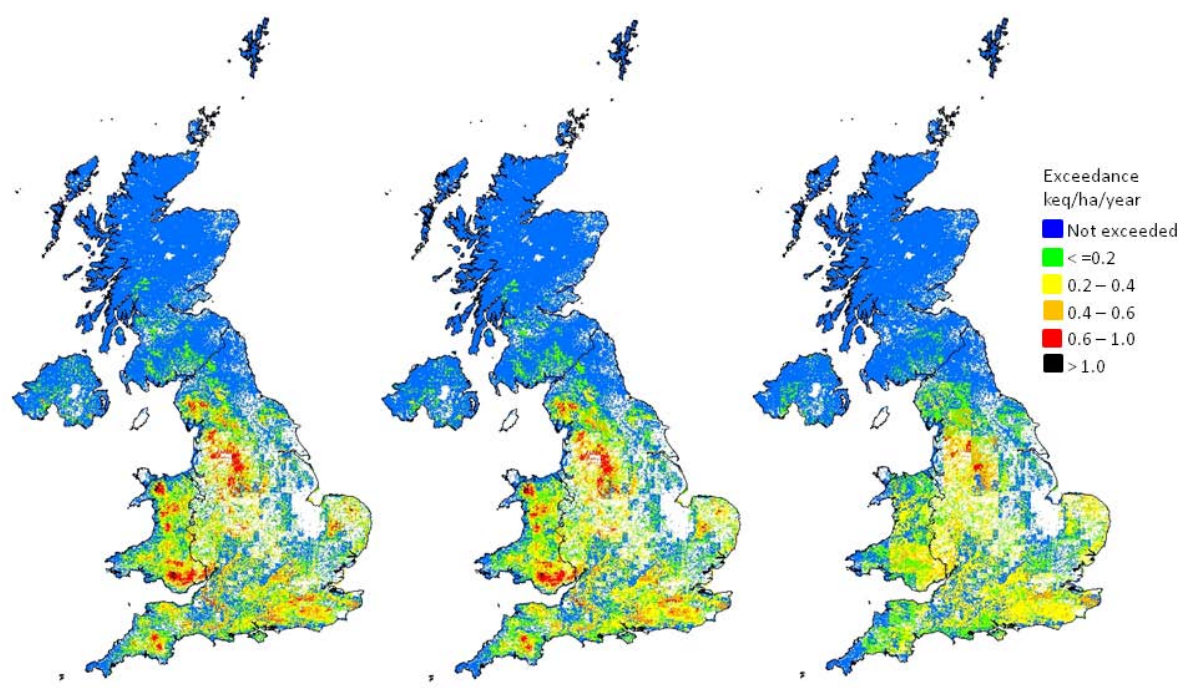

Fig. 6a. Exceedance of 5th percentile nutrient nitrogen critical loads for the UK using modelled deposition data with resolutions of: $1 \mathrm{~km}$ (left); $5 \mathrm{~km}$ (centre); $50 \mathrm{~km}$ (right).

variable in upland regions (i.e. Snowdonia) but less sensitive to grid resolution in the lowland areas where the collectors in the precipitation chemistry monitoring network are located. Here we consider model correlation with measurements of $\mathrm{NO}_{2}$ gas concentrations. In the UK, monitoring of $\mathrm{NO}_{2}$ concentrations is undertaken with both the rural monitoring network using diffusion tubes (20 sites) and the Automated Urban and Rural Network (AURN) using chemiluminescence. The 12 rural sites in the AURN are considered here for validation of the model. The AURN is intended to check if statutory air quality standards form EC Directives and targets are met and to identify long-term trends in air pollution concentrations. The rural monitoring network provides valuable information regarding background concentrations of $\mathrm{NO}_{2}$.

Figure 5 illustrates the correlation of the model with measurements of $\mathrm{NO}_{2}$ concentrations. The statistical analysis in Table 2 demonstrates clearly that there is an improved agreement with measurements of $\mathrm{NO}_{2}$ concentrations from both the rural monitoring network and the rural sites in the AURN using $1 \mathrm{~km}$ resolution gridded data as compared to $5 \mathrm{~km}$ or $50 \mathrm{~km}$ resolution. With the $1 \mathrm{~km}$ data, the lowest values for normalised mean bias, root mean square error and mean 
Table 2. Statistics for the model correlation with measurements of $\mathrm{NO}_{2}$ concentrations from the rural monitoring and Automated Urban and Rural monitoring Networks (rural sites only) with data gridded at $1 \mathrm{~km}, 5 \mathrm{~km}$ and $50 \mathrm{~km}$ resolution (mes: measured value; mod: modelled value). Units are in $\mu \mathrm{g} \mathrm{m}^{-3}$ except for the correlation coefficient which is dimensionless.

\begin{tabular}{lrrrrrrrr}
\hline & \multicolumn{3}{c}{ Rural network } & & \multicolumn{3}{c}{ AURN } \\
\cline { 2 - 5 } \cline { 8 - 9 } & $1 \mathrm{~km}$ & $5 \mathrm{~km}$ & $50 \mathrm{~km}$ & & $1 \mathrm{~km}$ & & $5 \mathrm{~km}$ & $50 \mathrm{~km}$ \\
\hline Maximum (mes - mod) value & 1.37 & 1.35 & 0.78 & & 6.88 & 6.64 & 6.63 \\
Minimum (mes - mod) value & & -5.5 & -5.5 & -8.1 & & -4.3 & -6.7 & -9.0 \\
Mean bias & 0.20 & 0.26 & 0.77 & & 0.18 & 0.64 & 2.2 \\
Mean average gross error & 0.98 & 1.02 & 1.05 & & 1.67 & 2.02 & 3.36 \\
Root mean square error & 1.62 & 1.63 & 2.02 & & 2.53 & 2.98 & 4.48 \\
Normalised mean bias & 0.039 & 0.050 & 0.152 & & 0.018 & & 0.064 & 0.220 \\
Normalised average mean error & 0.19 & 0.20 & 0.21 & & 0.17 & 0.20 & 0.34 \\
Correlation coefficient & 0.94 & 0.945 & 0.90 & & 0.82 & 0.81 & 0.80 \\
\hline
\end{tabular}

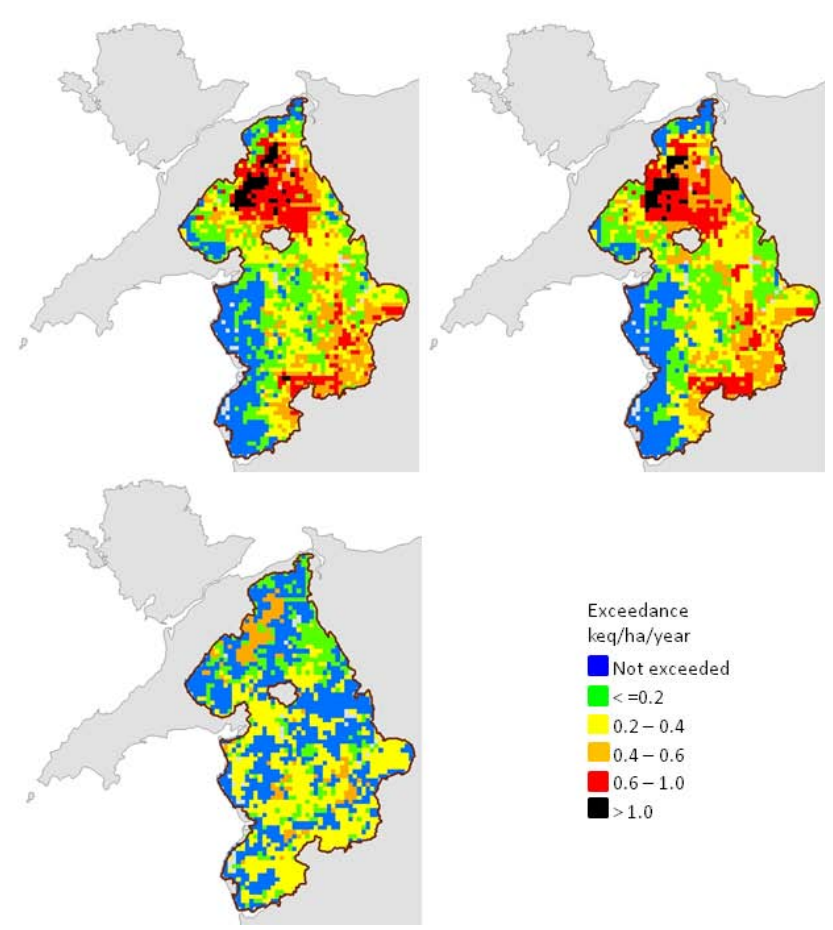

Fig. 6b. Exceedance of 5th percentile nutrient nitrogen critical loads for Snowdonia using model deposition data with resolutions of: $1 \mathrm{~km}$ (upper left); $5 \mathrm{~km}$ (upper right); $50 \mathrm{~km}$ (lower left).

average gross error are achieved. However there is only a relatively small improvement in some of these statistics for the $1 \mathrm{~km}$ resolution data when compared to the $5 \mathrm{~km}$ resolution data. Indeed, as illustrated in Fig. 5, at some sites, the $\mathrm{NO}_{2}$ concentrations with the $1 \mathrm{~km}$ resolution data are almost identical to those with the $5 \mathrm{~km}$ resolution data. This result can be explained by considering the criteria for defining a "rural" site which are that it should be located at least $2.5 \mathrm{~km}$ from a road. This means that the process of averaging $1 \times 1 \mathrm{~km}$ gridded concentration data over 25 squares to a $5 \times 5 \mathrm{~km}$ grid which contains a rural monitoring site is quite likely not to include any elevated $\mathrm{NO}_{2}$ concentrations from local traffic. As such, the design of the rural monitoring networks are not ideal for demonstrating the benefits of changing model grid resolution from $5 \times 5 \mathrm{~km}$ to $1 \times 1 \mathrm{~km}$ which are illustrated in Fig. 3a for Stanford Park SSSI.

\subsection{Exceedance of critical loads}

The amount of excess nitrogen deposition above the critical load (the exceedance) was calculated separately for each habitat type. Exceedances were calculated separately for each habitat type using $1 \mathrm{~km}$ critical loads data and ecosystem-specific deposition (i.e. moorland deposition for the grassland, heath, bog and montane habitats, and woodland deposition for the woodland habitats). However, rather than include separate exceedance maps for each habitat, the exceedance maps presented here (Fig. 6a and b) are based on 5th-percentile critical loads that combine data for all habitats. The 5th-percentile critical load is set to protect $95 \%$ of the total sensitive habitat area in each $1 \mathrm{~km}$ square.

The results of calculating exceedance of the critical load for nutrient nitrogen deposition for each habitat across the UK are summarised in Table $3 a$ and $b$. The influence of aggregating $1 \mathrm{~km}$ deposition data to a $5 \mathrm{~km}$ resolution grid is not manifested in a very large change in the percentage habitat area with exceedance of the critical load. The reason for this is the quasi-random distribution of source areas (i.e. industry, roads and agriculture) and sink areas (sensitive ecosystems). However, overall the exceedance of critical loads for nitrogen deposition is higher using the $5 \mathrm{~km}$ resolution data due to mixing of source areas (agriculture for reduced ammonia and road transport for oxidised nitrogen) with sensitive ecosystems in the same model grid square. With deposition data gridded at a $50 \mathrm{~km}$ resolution, the national scale area of ecosystem with exceedance is higher $(35.4 \%)$ than for $1 \mathrm{~km}$ data $(31.5 \%)$. This occurs because at the coarse $50 \mathrm{~km}$ resolution, nitrogen sources emitted from major industrial and urban areas are effectively co-located with natural ecosystems. 
Table 3a. National scale summary statistics for habitat areas with exceedance of the critical load for nutrient nitrogen deposition by region.

\begin{tabular}{|c|c|c|c|c|}
\hline \multirow[b]{2}{*}{ Country } & \multirow{2}{*}{$\begin{array}{r}\text { Habitat Area } \\
\qquad\left(\mathrm{km}^{2}\right)\end{array}$} & \multicolumn{3}{|c|}{$\begin{array}{l}\text { Percentage area habitats } \\
\text { exceeded using FRAME } \\
\text { deposition for } 2007 \text { at } \\
\text { the following resolutions: }\end{array}$} \\
\hline & & $1 \mathrm{~km}$ & $5 \mathrm{~km}$ & $50 \mathrm{~km}$ \\
\hline England & 20299 & 71.4 & 72.5 & 73.8 \\
\hline Wales & 7101 & 76.8 & 79.9 & 84.9 \\
\hline Scotland & 43530 & 5.1 & 5.6 & 7.5 \\
\hline Northern Ireland & 3500 & 37.3 & 40.3 & 58.0 \\
\hline UK & 74430 & 31.5 & 32.6 & 35.4 \\
\hline
\end{tabular}

Although the area exceeded was higher when using the $50 \mathrm{~km}$ deposition data, the magnitude of exceedance was lower. Use of $50 \mathrm{~km}$ resolution deposition resulted in spreading the exceedance wider, but with smaller resulting magnitude.

For regions with lower percentage area exceedance (Scotland and Northern Ireland), the influence of spatial averaging of nitrogen deposition over the larger $50 \mathrm{~km}$ grid cells resulted in more significant changes in total area with exceedance (i.e. from $5.1 \%$ for $1 \mathrm{~km}$ data to $7.5 \%$ for $50 \mathrm{~km}$ data for Scotland). For countries with higher percentage area exceedance (England and Wales) spatial averaging of deposition resulted in relatively small changes in the percentage in total area with exceedance (i.e. from $71.4 \%$ for $1 \mathrm{~km}$ data to $73.8 \%$ for $50 \mathrm{~km}$ data for England).

When percentage area exceedance is considered for the UK as a whole according to habitat type (Table 3b), the general trend for increased percentage area exceedance using data with larger grid spacing is apparent. However for certain habitats (notably montane) the opposite is true. For this vegetation type, lower exceedances were obtained with the $50 \mathrm{~km}$ data. This is due to the fact that this habitat is associated with upland high precipitation areas located almost predominantly in the Scottish Highlands and that spatial averaging over $50 \mathrm{~km}$ in these regions leads to reduced wet deposition of nitrogen at the high elevation sites.

Furthermore it should be noted that the importance of spatial resolution inevitably depends on the nature of the landscape and the level of spatial mixing between source areas of reactive nitrogen emissions (agriculture, roads and urban areas) and sink areas (natural ecosystems). For regions such as that illustrated in Fig. 3 (a site of Special Scientific Interest with a nearby strong source of reactive nitrogen emissions) spatial resolution will be of greater significance than for regions remote from emissions sources.

The exceedance of the 5th percentile critical load for nitrogen deposition for data gridded at $1 \mathrm{~km}, 5 \mathrm{~km}$ and $50 \mathrm{~km}$ resolution is illustrated as mapped data for the UK in Fig. 6a and for Snowdonia national park in Fig. 6b. A general
Table 3b. National scale summary statistics for habitat areas with exceedance of the critical load for nutrient nitrogen deposition by habitat type.

\begin{tabular}{|c|c|c|c|c|}
\hline \multirow[b]{2}{*}{ Broad habitat } & \multirow{2}{*}{$\begin{array}{r}\text { Habitat Area } \\
\qquad\left(\mathrm{km}^{2}\right)\end{array}$} & \multicolumn{3}{|c|}{$\begin{array}{l}\text { Percentage area habitats } \\
\text { exceeded using FRAME } \\
\text { deposition for } 2007 \text { at } \\
\text { the following resolutions: }\end{array}$} \\
\hline & & $1 \mathrm{~km}$ & $5 \mathrm{~km}$ & $50 \mathrm{~km}$ \\
\hline Acid grassland & 15247 & 27.8 & 29.3 & 32.0 \\
\hline Calcareous grassland & 3578 & 24.1 & 23.9 & 18.2 \\
\hline Dwarf shrub heath & 24826 & 9.6 & 10.2 & 11.6 \\
\hline Bog & 5537 & 25.7 & 26.9 & 35.8 \\
\hline Montane & 3129 & 7.3 & 5.8 & 0.6 \\
\hline Coniferous woodland (managed) & 8383 & 44.4 & 48.0 & 60.7 \\
\hline Broadleaved woodland (managed) & 7482 & 89.7 & 89.9 & 89.1 \\
\hline Unmanaged woods (ground flora) & 3297 & 85.8 & 86.0 & 86.2 \\
\hline Atlantic oak (epiphytic lichens) & 822 & 40.9 & 40.9 & 45.3 \\
\hline Supralittoral sediment & 2129 & 34.3 & 37.8 & 43.8 \\
\hline All habitats & 74430 & 31.5 & 32.6 & 35.4 \\
\hline
\end{tabular}

tendency is for the larger grid resolution data (i.e. $50 \mathrm{~km}$ ) to lead to greater areas with exceedance of the critical load but lower values of exceedance. For Snowdonia, the use of $50 \mathrm{~km}$ resolution data results in no exceedances greater than $0.6 \mathrm{keq} \mathrm{ha}^{-1}$ whereas with both $1 \mathrm{~km}$ and $5 \mathrm{~km}$ resolution data, exceedances were higher than $1.0 \mathrm{keq} \mathrm{ha}^{-1}$ in many high precipitation upland regions.

\section{Conclusions}

An atmospheric transport model has been run at a resolution of $1 \mathrm{~km}$ over the UK. The data on concentrations of reactive nitrogen compounds in air as well as wet and dry deposition of nitrogen was gridded at three resolutions: $1 \mathrm{~km}, 5 \mathrm{~km}$ and $50 \mathrm{~km}$.

The high resolution $1 \mathrm{~km}$ data was found to be an improvement for investigating nitrogen deposition and exceedance of critical loads in areas with high emissions of ammonia from agriculture (i.e. Hallsworth et al., 2010) and high emissions of $\mathrm{NO}_{\mathrm{x}}$ from road transport as well as in high precipitation upland areas (this study). Validation of the modelled $\mathrm{NO}_{2}$ concentrations by comparison with measurements from rural sites demonstrated an improved correlation using the higher resolution $1 \mathrm{~km}$ data.

National scale statistics for exceedance of the critical load for nitrogen deposition were not highly sensitive to the resolution of the modelled data. However, the effect of spatial averaging resulted in greater areas with exceedance using the coarser $50 \mathrm{~km}$ resolution data and the lowest areas with exceedance using the $1 \mathrm{~km}$ data (but with lower values of exceedance at the higher resolution). For certain ecosystems (i.e. montane), the national scale exceedance statistics were particularly sensitive to the grid resolution of the modelled data. For regions with generally low area exceedance (i.e. Scotland) the area exceedance was more sensitive to model 
data resolution than regions with higher area exceedance (i.e. England).

In conclusion, the $1 \mathrm{~km}$ resolution data set provides an improved reference data set for local studies on acidifying and eutrophying effects of nitrogen deposition, in particular when data from specific local dispersion models is absent. High resolution data is of particular importance for upland regions with high precipitation or for Sites of Special Scientific Interest located near to major sources of emissions such as road transport or agriculture. The increase in model simulation time (from $20 \mathrm{~min}$ for $5 \mathrm{~km}$ resolution to $12 \mathrm{~h}$ for $1 \mathrm{~km}$ resolution) permits multiple emissions scenarios to be undertaken at a $1 \mathrm{~km}$ resolution.

Accurate assessment of nitrogen deposition at fine resolution relies on detailed emissions maps of both oxidised and reduced nitrogen. Improvements in information on the spatial distribution of livestock numbers and on agricultural practice and the dependence of emissions on meteorological variables (i.e. temperature, precipitation, wind speed) are necessary to achieve better estimates of nitrogen dry deposition. In upland areas, containing sensitive ecosystems, wet deposition is an important pathway for nitrogen input. Widespread monitoring and accurate modelling and mapping of precipitation in hill regions are required to improve estimates of nitrogen deposition in these regions. Uncertainties in these areas need to be reduced in order to fully benefit from the ability of models to undertake high resolution simulations.

Acknowledgements. This work was funded by the UK Department for the Environment, Food and Rural Affairs and the Devolved Administrations as well as the Natural Environment Research Council.

Edited by: A. R. Mosier

\section{References}

Achermann, B. and Bobbink, R. (Eds.): Empirical critical loads for nitrogen. Proceedings of an Expert Workshop, 11-13 November 2002, Berne, Environmental Documentation No. 164, Swiss Agency for the Environment, Forests and Landscape, Berne, 2003.

Appel, K. W., Foley, K. M., Bash, J. O., Pinder, R. W., Dennis, R. L., Allen, D. J., and Pickering, K.: A multi-resolution assessment of the Community Multiscale Air Quality (CMAQ) model v4.7 wet deposition estimates for 2002-2006, Geosci. Model Dev., 4, 357-371, doi:10.5194/gmd-4-357-2011, 2011.

Bobbink, R. and Hettelingh, J. P. (Eds.): Review and revision of empirical critical loads and dose response relationships, Coordination Centre for Effects, National Institute for Publich Health and the Environment (RIVM), available at: www.rivm.nl/cce (last access: 27 April 2012), 2011.

Bobbink, R., Hornung, M., and Roelofs, J. G. M.: The effects of air-borne nitrogen pollutants on species diversity in natural and semi-natural European vegetation, J. Ecol., 86, 717-738, 1998.
Carruthers, D. J., Seaton, M. D., McHugh, C. A., Sheng, X. Y., Solazzo, E., and Vanyve, E.: Comparison of the complex terrain algorithms incorporated into two commonly used local-scale air pollution dispersion models (ADMS and AEROMOD) using a hybrid model, J. Air Waste Manage., 61, 1277-1235, 2011.

Carslaw, D.: Defra deposition model evaluation analysis Phase 1, available at: http://uk-air.defra.gov.uk/reports/ (last access: 27 April 2012), 2011.

Chaney, A. M., Cryer, D. J., Nicholl, E. J., and Seakins, P. W.: $\mathrm{NO}$ and $\mathrm{NO}_{2}$ inter-conversion downwind of two different line sources in suburban environments, Atmos. Environ., 45, 58635871, 2011.

Chemel, C., Sokhi, R. S., Yu, Y., Hayman, G. D., Vincent, K. J., Dore, A. J., Prain, H. D., and Fisher, B. E. A.: Evaluation of a CMAQ simulation at high resolution over the UK for the calendar year 2003, Atmos. Environ., 44, 2927-2939, 2010.

Chemel, C., Sokhi, R. S., Dore, A. J., Sutton, P., Vincent, K. J., Griffiths, S. J., Hayman, G. D., Wright, R., Baggaley, M., Hallsworth, S., Prain, H. D., and Fisher, B. E. A.: Predictions of UK Regulated Power Station Contributions to Regional Air Pollution and Deposition: A Model Comparison Exercise, J. Air Waste Manage., 61, 1236-1245, 2011.

Clarisse, L., Clerbaux, C., Dentener, F., Hurtmans, D., and Coheur, P. F.: Global ammonia distribution derived from infrared satellite observations, Nat. Geosci., 2, 479-483, 2009.

Davies, C. E., Moss, D., and Hill, M. O.: EUNIS habitat classification revised 2004, European Environment Agency, European Topic Centre on Nature Protection and Biodiversity, 2004.

Dore, A. J., Vieno, M., Fournier, N., Weston, K. J., and Sutton, M. A.: Development of a new wind rose for the British Isles using radiosonde data and application to an atmospheric transport model, Q. J. Roy. Meteor. Soc., 132, 2769-2784, 2006 a.

Dore, A. J., Mousavi-Baygi, M., Smith, R. I., Hall, J., Fowler, D., and Choularton, T. W.: A model of annual orographic precipitation and acid deposition and its application to Snowdonia, Atmos. Environ., 40, 3316-3326, doi:10.1016/j.atmosenv.2006.01.043, 2006b.

Dore, A. J., Vieno, M., Tang, Y. S., Dragosits, U., Dosio, A., Weston, K. J., and Sutton, M. A.: Modelling the atmospheric transport and deposition of sulphur and nitrogen over the United Kingdom and assessment of the influence of $\mathrm{SO}_{2}$ emissions from international shipping, Atmos. Environ., 41, 2355-2367, doi:10.1016/j.atmosenv.2006.11.013, 2007.

Fagerli, H., Gauss, M., Benedictow, A., Griesfeller, J., Eiof Jonson, J., Nýrír, A., Schulz, M., Simpson, D., Steensen, B., Tsyro, S., Valdebenito, A., Wind, P., Aas, W., Hjellbrekke, A., Mareckova, K., Wankmüller, R., Iversen, T., Kirkevåg, A., Seland, Ø., and Vieno, M.: Transboundary Acidification, Eutrophication and Ground Level Ozone in Europe in 2000, EMEP Report 1/2011, July 2011, 2011.

Fournier, N., Dore, A. J., Vieno, M., Weston, K. J., Dragosits, U., and Sutton, M. A.: Modelling the deposition of atmospheric oxidised nitrogen and sulphur to the United Kingdom using a multilayer long-range transport model, Atmos. Environ., 38, 683-694, 2004.

Fournier, N., Weston, K. J., Dore, A. J., and Sutton, M. A.: Modelling the wet deposition of reduced nitrogen over the British Isles using a Lagrangian multi-layer atmospheric transport model, Q. J. Roy. Meteor. Soc., 131, 703-722, 2005. 
Fowler, D., Cape, J. N., Leith, I. D., Choularton, T. W., Gay, M. J., and Jones, A.: The influence of altitude on rainfall composition, Atmos. Environ., 22, 1355-1362, 1988.

Fowler, D., Pitcairn, C. E. R., Sutton, M. A., Flechard, C., Loubet, B., Coyle, M., and Munro, R. C.: The mass budget of atmospheric ammonia in woodland within $1 \mathrm{~km}$ of livestock buildings, Environ. Pollut., 102, 343-348, 1998.

Geels, C., Andersen, H. V., Ambelas Skjøth, C., Christensen, J. H., Ellermann, T., Løfstrøm, P., Gyldenkærne, S., Brandt, J., Hansen, K. M., Frohn, L. M., and Hertel, O.: Improved modelling of atmospheric ammonia over Denmark using the coupled modelling system DAMOS, Biogeosciences Discuss., 9, 1587-1634, doi:10.5194/bgd-9-1587-2012, 2012.

Gyldenkaerne, S., Ambelas Skjøth, C., Hertel, O., and Ellermann, T.: A dynamical ammonia emission parameterization for use in air pollution models, J. Geophys. Res., 110, D07108, doi:10.1029/2004JD005459, 2005.

Hall, J., Ullyett, J., Heywood, L., Broughton, R., Fawehinmi, J., and 31 UK experts: Status of UK critical loads: Critical load methods, data and maps, February 2003, Report to Defra (Contract EPG 1/3/185), available at: http://cldm.defra.gov.uk/ (last access: 27 April 2012), 2003.

Hall, J., Emmett, B., Garbutt, A., Jones, L., Rowe, E., Sheppard, L., Vanguelova, E., Pitman, R., Britton, A., Hester, A., Ashmore, M., Power, S., and Caporn, S.: UK Status Report July 2011: Update to empirical critical loads of nitrogen, Report to Defra under contract AQ801 Critical Loads and Dynamic Modelling, available at: http://cldm.defra.gov.uk/Status_Reports.htm (last access: 27 April 2012), 2011.

Hallsworth, S., Sutton, M. A., Dore, A. J., Dragosits, U., Tang, Y. S., and Vieno, M.: The role of indicator choice in quantifying the ammonia threat to the "Natura 2000" network, Environ. Sci. Policy, 13, 671-687, doi:10.1016/j.envsci.2010.09.010, 2010.

Hertel, O., Skjøth, C. A., Lofstrom, P., Geels, C., Frohn, L. M., Ellermann, T., and Madsen, P. V.: Modelling nitrogen deposition on a local scale - A review of the current state of the art, Environ. Chem., 3, 317-337, 2006.

Hertel, O., Geels, C. Frohn, L. M., Ellermann, T., Skjøth, C. A., Løfstrøm, P., Christensen, J. H., Andersen, H. V., and Pee, R. G.: Assessing atmospheric nitrogen deposition to natural and seminatural ecosystems - experience from Danish studies using the DAMOS system, Atmos. Environ., in press, 2012.

Keller, V., Young, A. R., Morris, D., and Davies, H.: Continuous Estimation of River Flows (CERF) Technical Report: Task 1.1: Estimation of Precipitation Inputs Environment Agency R \& D Project W6-101, 1-36, 2006.

Kryza, M., Dore, A. J., Błaś, M., and Sobik, M.: Modelling deposition and air concentration of reduced nitrogen in Poland and sensitivity to variability in annual meteorology, J. Environ. Manage., 92, 1225-1236, 2011.

Matejko, M., Dore, A. J., Hall, J., Dore, C. J., Błaś, M., Kryza, M., Smith, R., and Fowler, D.: The influence of long term trends in pollutant emissions on deposition of sulphur and nitrogen and exceedance of critical loads in the United Kingdom, Environ. Sci. Policy, 12, 882-896, 2009.
Richard, E., Buzzi, A., and Zangl, G.: Quantitative precipitation forecasting in the Alps: The advances achieved by the Mesoscale Alpine Programme, Q. J. Roy. Meteor. Soc., 133, 831-846, 2007.

RoTAP: Review of Transboundary Air Pollution. Acidification, Eutrophication, Ground-Level Ozone and Heavy Metals in the UK, available at: http://www.rotap.ceh.ac.uk/ (last access: 27 April 2012), 2012.

Sala, O. E., Chapin, F. S., Armesto, J. J., Berlow, E., Bloomfield, J., Dirzo, R., Huber-Sanwald, E., Huenneke, L. F., Jackson, R. B., Kinzig, A., Leemans, R., Lodge, D. M., Mooney, H. A., Oesterheld, M., LeRoy Poff, N., Sykes, M. T., Walker, B. H., Walker, M., and Wall, D. H.: Global biodiversity scenarios for the year 2100, Science, 287, 1770-1774, 2000.

Seinfield, J. H. and Pandis, S. N.: Atmospheric Chemistry and Physics, John Wiley \& Sons Inc., 1998.

Singles, R., Sutton, M. A., and Weston, K. J.: A multi-layer model to describe the atmospheric transport and deposition of ammonia in Great Britain, Atmos. Environ., 32, 393-399, 1998.

Skjøth, C. A., Geels, C., Berge, H., Gyldenkærne, S., Fagerli, H., Ellermann, T., Frohn, L. M., Christensen, J., Hansen, K. M., Hansen, K., and Hertel, O.: Spatial and temporal variations in ammonia emissions - a freely accessible model code for Europe, Atmos. Chem. Phys., 11, 5221-5236, doi:10.5194/acp-11-52212011, 2011.

Sutton, M. A., Dragosits, U., Tang, Y. S., and Fowler, D.: Ammonia emissions from non-agricultural sources in the UK, Atmos. Environ., 34, 855-869, 2000.

UBA: Manual on Methodologies and Criteria for Modelling and Mapping Critical Loads and Levels; and Air Pollution Effects, Risks and Trends, Umweltbundesamt, Berlin, available at: http://www.rivm.nl/en/themasites/icpmm/index.html (last access: 27 April 2012), 2004.

Van Pul, A., Van Jaarsveld, H., Van der Meulen, T., and Velders, G.: Ammonia concentrations in the Netherlands: spatially detailed measurements and model calculations, Atmos. Environ., 38, 4045-4055, 2004.

Vieno, M., Dore, A. J., Stevenson, D. S., Doherty, R., Heal, M. R., Reis, S., Hallsworth, S., Tarrason, L., Wind, P., Fowler, D., Simpson, D., and Sutton, M. A.: Modelling surface ozone during the 2003 heat-wave in the UK, Atmos. Chem. Phys., 10, 7963-7978, doi:10.5194/acp-10-7963-2010, 2010a.

Vieno, M., Dore, A. J., Bealey, W. J., Stevenson, D. S., and Sutton, M. A.: The importance of source configuration in quantifying footprints of regional atmospheric sulphur deposition, Sci. Total Environ., 408, 985-995, 2010b.

Vogt, E., Dragosits, U., Braban, C. E., Theobald, M. R., Dore, A. J., van Dijk, N., Tang, Y. S., McDonald, C., Murray, and Sutton, M. A.: Heterogeneity of atmospheric ammonia at the landscape scale and its consequences for environmental impact assessment, Atmos. Environ., in preparation, 2012.

Zhang, Y., Dore, A. J., Liu, X., and Zhang, F.: Simulation of nitrogen deposition in the North China Plain by the FRAME model, Biogeosciences, 8, 3319-3329, doi:10.5194/bg-8-33192011, 2011. 